\title{
Inferring vertical and horizontal movements of juvenile marine turtles from time-depth recorders
}

\author{
Matthew J. Witt ${ }^{1}$, Andrew McGowan ${ }^{1}$, Janice M. Blumenthal ${ }^{1,2}$, Annette C. Broderick ${ }^{1}$, \\ Shannon Gore ${ }^{3}$, Damon Wheatley ${ }^{4}$, James White ${ }^{4}$, Brendan J. Godley ${ }^{1, *}$ \\ ${ }^{1}$ University of Exeter, Centre for Ecology and Conservation, School of Biosciences, Tremough Campus, Penryn, \\ Cornwall TR10 9EZ, UK \\ ${ }^{2}$ Department of Environment, PO Box 486, Grand Cayman KY1-1106, Cayman Islands \\ ${ }^{3}$ BVI Conservation and Fisheries Department, Road Town, Tortola, British Virgin Islands \\ ${ }^{4}$ The Settlement, Anegada, British Virgin Islands
}

\begin{abstract}
Acquiring knowledge of the spatial ecology of many aquatic species, particularly their juvenile life stages, is challenging when they are small in size; this limits the attachment of tracking devices that routinely provide spatially explicit information on larger juveniles and adults. Using depth utilisation data gathered by time-depth recorders, we inferred patterns of habitat utilisation of juvenile hawksbill turtles Eretmochelys imbricata occupying a shallow reef system in the Caribbean. Hawksbill turtles $(\mathrm{n}=9$, curved carapace length $=42.3 \pm 9.7 \mathrm{~cm}$, range $=27.7$ to $60.0 \mathrm{~cm}$ ) demonstrated diel patterns of behaviour, with greater activity and shorter dives during the day (mean duration $=7.5 \pm 5.0 \mathrm{~min}$, range $=2.6$ to $34.4 \mathrm{~min}$ ) and longer, less active dives during the night (mean duration $=16.6 \pm 12.0 \mathrm{~min}$, range $=2.5$ to $61.5 \mathrm{~min}$ ). A level of fidelity to sites facilitated recaptures (mean minimum straight-line distance from release of TDR-equipped turtles to their subsequent recapture locations $=0.9 \pm 0.9 \mathrm{~km}$, range $=0.01$ to $2.3 \mathrm{~km}$ ), but recapture success after $130 \mathrm{~h}$, over a $43 \mathrm{~d}$ period, was relatively low: of 19 individuals instrumented, 9 were recaptured. From depth records, i.e. maximum depths achieved, it was clear that some recaptured individuals moved considerably during the monitoring period; 3 individuals moved to deeper waters, with minimum possible straight-line movement distances from their capture sites of 3.7 to $9.2 \mathrm{~km}$. These findings emphasize the likely influence of habitat structure on site fidelity and further highlight that data from traditional capture-markrecapture studies could lead to an underestimation of home-range size.
\end{abstract}

KEY WORDS: Habitat utilisation - Spatial ecology $\cdot$ Coral reef $\cdot$ Hawksbill turtle $\cdot$ Eretmochelys imbricata $\cdot$ Telemetry $\cdot$ British Virgin Islands

Resale or republication not permitted without written consent of the publisher

\section{INTRODUCTION}

While the horizontal and vertical movements of large marine vertebrates are being increasingly described (Priede 1984, Duron-Dufrenne 1987, Polovina et al. 2000, Block et al. 2005, Bonfil et al. 2005), remote recording of accurate spatial movements made by smaller species or early life stages has been slower, due to the challenges of miniaturising power sources, development of attachment techniques and hydrodynamic packaging of equipment (Watson \& Granger 1998, Wilson \& McMahon 2006, Pavlov et al. 2007, Godley et al. 2008).
For many species this problem has set limits on the size classes that can be tracked with the more sophisticated, power- and memory-demanding biologging technologies, such as satellite tracking units and deadreckoning technologies. Many aspects of juvenile behaviour have, therefore, remained elusive to ecologists and conservation managers seeking to develop spatially explicit management plans.

The time-depth recorder (TDR) represents a useful and cost-effective technology for studying depthutilisation in juvenile life stages, as units are typically small and comparatively inexpensive. TDRs, however, 
record only depth and, optionally, light and/or temperature. These data make it difficult to ascertain habitat use within a spatial context, particularly for species or life stages that have patterns of movement or habitat preferences not well suited for light geolocation techniques (i.e. crepuscular diving, preference for turbid water, or non-migratory behaviour). It has, however, been possible to use TDR data, alongside environmental data, to reconstruct the migratory routes of freeranging fish species (Metcalfe \& Arnold 1997, Hunter et al. 2003, Hunter et al. 2006, Righton \& Mills 2008).

Adult hawksbill turtles Eretmochelys imbricata undertake considerable migrations between breeding grounds and subsequent coral reef foraging habitats (van Dam et al. 2008, Cuevas et al. 2008), which are also the foraging habitats of juveniles recruiting from oceanic environments (Musick \& Limpus 1997), a process that is accompanied by an ontogenetic dietary shift to predominant spongivory (Meylan 1988, Bjorndal 1997). Hawksbill turtles represent an important predator on sponges in reef systems (Hill 1998, Leon \& Bjorndal 2002). Reef occupancy will be driven by several factors, including the spatial distribution of preferred dietary items (Meylan 1988), an individual's relative capacity to dive to exploit these items and predator avoidance tactics (van Dam \& Diez 1996). As their mass and subsequent capacity to attain greater dive depths increases (Mori 2002, Hochscheid et al. 2007), larger juvenile turtles are able to transit to deeper habitats in search of food, most likely driving niche partitioning (Blumenthal et al. 2009b). Previous work has suggested that although juveniles make sequential moves between foraging grounds (Meylan 1999), home ranges are typically small (0.07 to $0.14 \mathrm{~km}^{2}$, van Dam \& Diez 1998; $545 \pm 515 \mathrm{~m}$ capture to recapture, Blumenthal et al. 2009a).

Previous TDR studies on hawksbill turtles have been carried out in the vicinity of reef wall habitats in Puerto Rico (van Dam \& Diez 1996, 1997) and the Cayman Islands (Blumenthal et al. 2009b). Here we assessed patterns of habitat utilisation in an extensive shallow reef system to ascertain whether there was any sizespecific structuring and diel patterns. Additionally, we determined the degree of site fidelity.

\section{MATERIALS AND METHODS}

Study site. Anegada $\left(18.7^{\circ} \mathrm{N}, 64.3^{\circ} \mathrm{W}\right)$ is a crescentshaped island of the British Virgin Islands archipelago in the eastern Caribbean Sea (Fig. 1a). The southern nearshore region of Anegada hosts tidally dominated habitats, including patch reefs and mangroves. Sea surface areas circumscribed by water depths of $0-5$, 5-10 and 10-20 $\mathrm{m}$ are 136, 87 and $567 \mathrm{~km}^{2}$, respec- tively. These habitats have been the focus of research investigating the composition and life history traits of juvenile hawksbill turtles (McGowan et al. 2008).

Turtle capture, instrumentation, release and recapture. Hawksbill turtles were caught using a rodeo style technique (Limpus \& Reed 1985) by crew members surveying aboard a Boston whaler throughout July-September 2005. Captured hawksbill turtles were instrumented with TDRs (model LTD1110, Lotek, weight in air $5.4 \mathrm{~g}$ ) and acoustic transmitters (models V13 and V16, Vemco, weight in air 11.4 and $24.9 \mathrm{~g}$, respectively). Morphometric measurements were recorded for each captured turtle, including mass and curved carapace length (CCL), a common measure of body size in marine turtles (Bolten 1999). Seabed depth (m), measured using a hand-held depth echo-sounder, and a GPS-derived position were recorded for each capture, release and recapture location. TDRs recorded pressure (pounds per square inch, psi) and ambient temperature $\left({ }^{\circ} \mathrm{C}\right)$ at a frequency of $10 \mathrm{~s}$ to a maximum of $7.6 \mathrm{~d}$ with a depth resolution of $0.05 \mathrm{~m}$ with $\pm 1 \%$ accuracy. TDRs and acoustic transmitters were housed together in bespoke plastic units (Blumenthal et al. 2009b). The mean total package mass, including an estimated mass for epoxy, as a percentage of body mass (in air) was $0.95 \pm 0.66 \%$ (range $=0.24$ to $2.57 \%$ ) and therefore negligible in water. Each unit was attached to the posterior left or right section of the carapace using 2-part epoxy resin (Power-Fast). All instrumented turtles were released as close as possible to the capture location, showing no apparent problems with diving or surfacing. Turtles instrumented with TDR-acoustic transmitter packages were held for no longer than $2 \mathrm{~h}$ between capture and release. Using an acoustic receiver (VR100, Vemco), the study area was surveyed to relocate instrumented turtles from $5 \mathrm{~d}$ following the deployment of the first TDR. All turtles sighted during surveying were, where possible, recaptured.

Mapping turtle captures and surveying effort. To construct a generalised pattern of hawksbill turtle capture locations, we applied a quartic kernelling technique, i.e. spatial point pattern smoothing, to all capture locations $(\mathrm{n}=104$ captures, gridding interval = $100 \mathrm{~m}$, smoothing parameter $=750 \mathrm{~m}$; Fig. 1b). To derive the spatial distribution of survey effort, we resampled the daily boat survey route, which was recorded continuously by a hand-held GPS receiver, to a 1 min time interval using linear interpolation. The spatial density of survey effort was then mapped using an equal-area grid where each cell represented $0.25 \mathrm{~km}^{2}$. Recapture effort initially focused on the region where captures had occurred, but was subsequently extended. Approximately $130 \mathrm{~h}$, over $43 \mathrm{~d}$, were expended attempting to recapture study animals. When instrumented turtles were recaptured, housings 

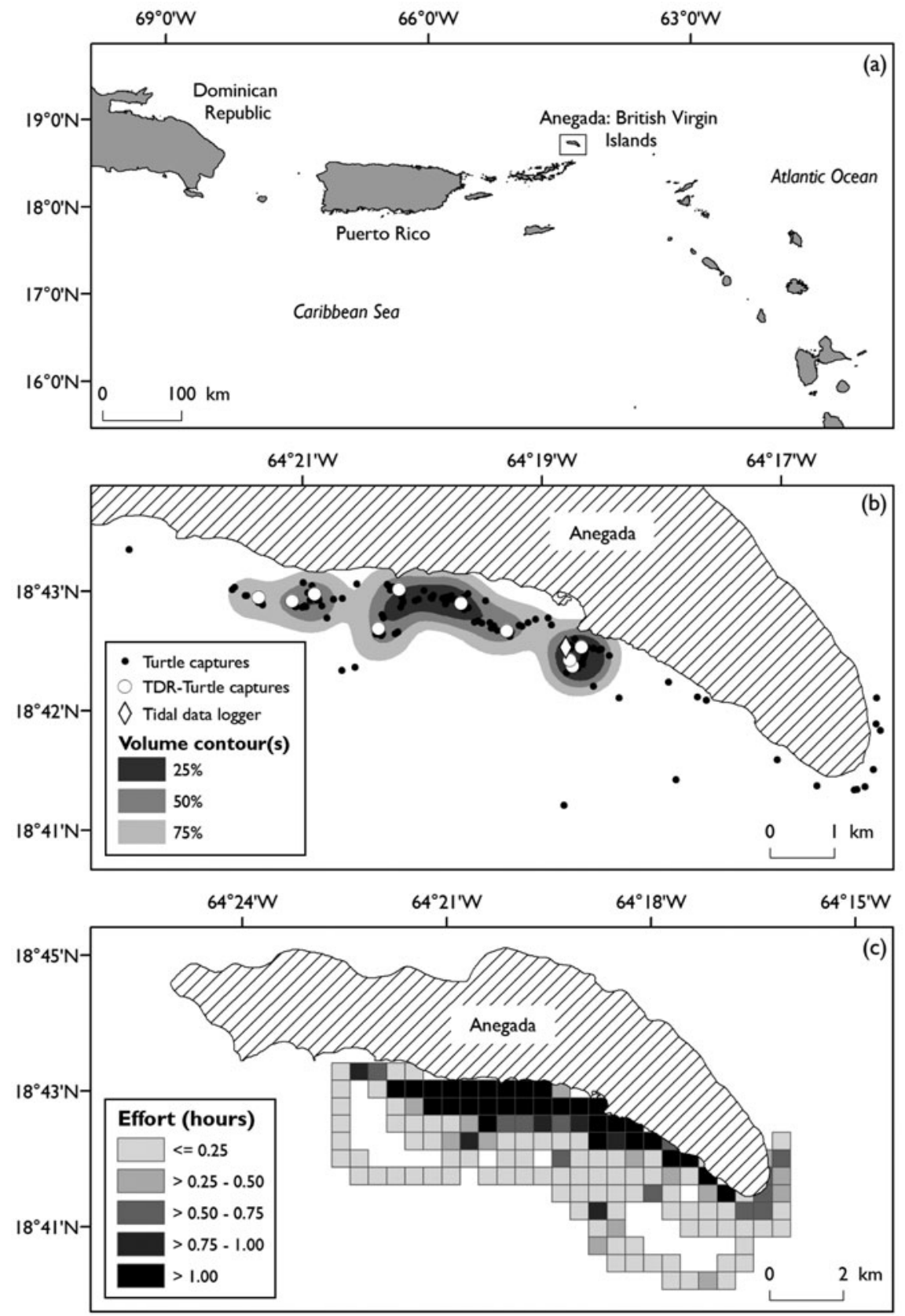

Fig. 1. Study site, turtle captures and survey effort. (a) British Virgin Islands. (b) Locations of all hawksbill turtle captures $(\bullet)$, capture locations of hawksbill turtles instrumented with time-depth recorders (TDRs) that were subsequently recaptured $(\mathrm{n}=10, \mathrm{O})$ and quartic kernelling indicating spatial density of all capture events (volume contours). (c) Survey effort (h) defined using an equal-area grid, where each cell represents $0.25 \mathrm{~km}^{2}$

were removed without causing damage to the carapace and turtles were subsequently released in the vicinity of the recapture location.

Tidal data and digital elevation model. Data on the tidal movement of water in the study area, during TDR deployments, were recorded at a 10 min frequency using a pressure (depth) logger attached to the seabed
(Minilog, Vemco; Fig. 1b). A digital elevation model of the local seabed was constructed from navigation charts (Imray Lolaire, chart A232 and United Kingdom Hydrographic Office, chart 2006). These charts were georeferenced in ArcMap (ESRI) and the geographic position of depth soundings transcribed. In addition, measurements of seabed depth $(\mathrm{n}=248$, range $=0.1$ to $4.6 \mathrm{~m}$ ) were also taken using a hand-held echo-sounder at locations of turtle captures over a 2 yr period. Depth soundings from both sources were collectively used to form a continuous surface of depth at a $50 \times 50 \mathrm{~m}$ horizontal resolution using cubic spline interpolation.

TDR data analysis. Pressure and temperature data were downloaded from each retrieved TDR. Pressure data were converted to depth using the relationship $1 \mathrm{~m}=1.45$ psi. To ensure all surfacing events occurred at $0 \mathrm{~m}$ depth, a correction was applied to each TDR data set. On an hourly basis the difference between the minimum depth value and zero was ascertained. All depths recorded within that hour were subsequently corrected by this difference. We chose a $1 \mathrm{~h}$ correction frequency as dives during hours of darkness were typically extended with only 2 or 3 surfacing intervals per hour. Dives were considered to be periods of submergence greater than $0.3 \mathrm{~m}$ depth in excess of $1 \mathrm{~min}$. For each TDR data set we determined the absolute maximum depth recorded and calculated individual dive summary metrics using custom written Matlab script (Version 7.8.0, MathWorks); these metrics included dive duration, maximum dive depth and coefficient of variation (CV) (Zar 1999). CV was calculated as an approximate measure of activity during dives based on the assumption that dives with greater activity, e.g. dives involving commuting and foraging, would demonstrate greater variability in depth then less active dives, e.g. resting dives. These dive-based metrics were subsequently aggregated by time, i.e. day and night, to produce mean dive duration, mean maximum dive depth and mean CV for each day and night of deployment. Due to the shallow nature of the occupied habitat, we calculated $\mathrm{CV}$ for each dive using all depth data greater than the $0.3 \mathrm{~m}$ depth threshold. Periods of 
day and night were defined by civil dawn and dusk times for each TDR data set using solar position equations available from NOAA (www.srrb.noaa.gov/highlights/sunrise/solareqns.PDF). Relationships between time of day and dive metrics were assessed using generalised linear mixed models (GLMM) in GenStat (12th edition, VSN International), controlling for the effect of individual and specifying either a Poisson error distribution with a logarithm link function, due to non-normal distributions of dive depth and duration data, or a normal distribution with a logit link function for dive CV. Relationship between body size and dive duration, while controlling for individual and time of day, was similarly assessed using GLMM utilising a Poisson distribution and a logarithm link function. The significance of statistical relationships was assessed using Wald statistics.

Inferring habitat utilisation. TDR data from each turtle were resolved to hourly maximum depths; these depths were then tidally corrected using the temporally closest water-column depth recorded by the tidal logger. Maximum extents of movement were determined by interrogating the digital elevation model with respect to these calculated seabed depths from maximum dive depths.

\section{RESULTS}

\section{Survey effort, captured turtles and instrumentation}

A total of 19 hawksbill turtles (mean \pm SD $\mathrm{CCL}=42.3 \pm 9.7 \mathrm{~cm}$, range $=27.7$ to $60.0 \mathrm{~cm}$ ) were fitted with TDRs and acoustic transmitters. Recaptured turtles were at liberty for $13.9 \pm 12.2 \mathrm{~d}$ (range $=4.9$ to $34.8 \mathrm{~d}_{i} \mathrm{n}=10$ ). Depth utilisation data from release to recapture were obtained from 4 of these turtles, and a further TDR dataset was found to be corrupt. For the remaining 5 turtles, $16.0 \pm 11.2 \mathrm{~d}$ (range $=$ 1.2 to $28.5 \mathrm{~d}$ ) elapsed between TDR memory exhaustion and recapture. Mean CCL of the recaptured group $(\mathrm{n}=10)$ was $41.4 \pm$ $10.1 \mathrm{~cm}$ (range $=29.5$ to $58.2 \mathrm{~cm}$, median $=$ $41.8 \mathrm{~cm})$. Mean CCL of turtles not recaptured $(\mathrm{n}=9)$ was $43.2 \pm 9.9 \mathrm{~cm}$ (range = 27.7 to $60.0 \mathrm{~cm}$, median $=41.5 \mathrm{~cm})$. The median CCL of these 2 groups did not differ significantly (Wilcoxon rank sum test, signed rank $=95, p=0.72$ ).
The capture locations of hawksbill turtles selected for instrumentation occurred within the $0-25 \%(n=7)$, $25-50 \%(n=5), 50-75 \%(n=4)$ and $75-95 \%(n=2)$ kernelled regions of all turtle initial capture locations (Fig. 1b). The capture location of 1 instrumented individual could not be recorded due to a faulty GPS; this individual was not recaptured.

The mean minimum straight-line distance between the locations of capture and recapture was $0.9 \pm 0.8 \mathrm{~km}$ (range $=0.1$ to $2.3 \mathrm{~km}$; Fig. 2). These distances did not
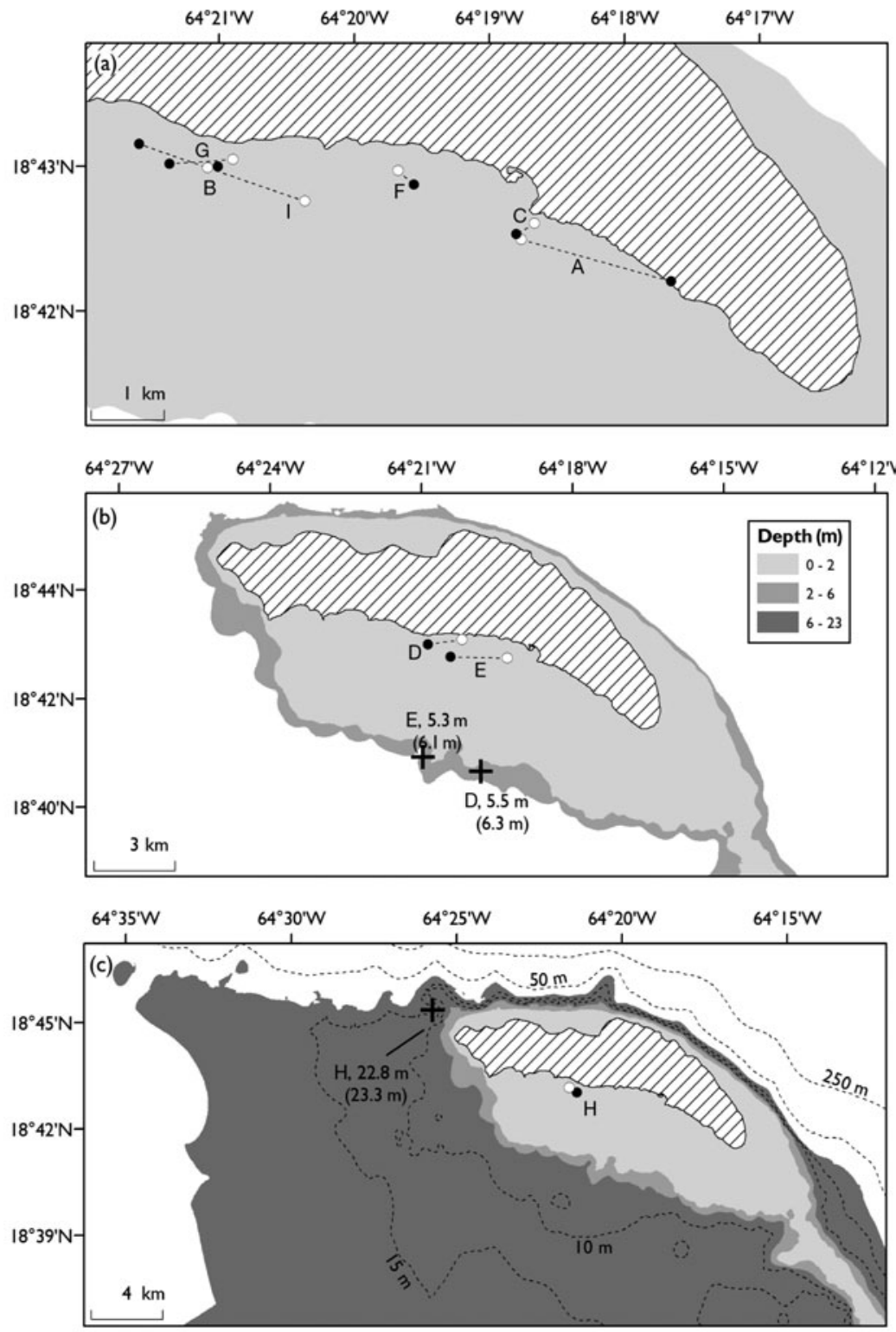

Fig. 2. Eretmochelys imbricata. (a) Capture (O) and recapture (•) locations of 6 hawksbill turtles (A-C, F, G and I) whose maximum depths were limited to $<3 \mathrm{~m}$. Dashed lines are minimum straight-line connections between capture and recapture locations. (b) As for (a) but for Turtles D and E, with location (+) and seabed depth for location of maximum dive depths (in parentheses). (c) As for (b), but for Turtle $\mathrm{H}_{\text {; }}$ distance between release and recapture of Turtle $\mathrm{H}=10 \mathrm{~m}$ 
correlate with respective at-liberty durations (Spearman rank correlation, $\left.\mathrm{r}_{\mathrm{S}}=-0.18, \mathrm{p}=0.64\right)$ or CCL $\left(\mathrm{r}_{\mathrm{S}}=\right.$ $0.10, \mathrm{p}=0.80$ ).

\section{Diving behaviour}

Turtles with usable TDR data sets $(n=9)$ are referred to here as turtles A to I based on increasing CCL. Data recorded by TDRs prior to the first midnight of deployment were withheld from statistical analysis. Instrumented turtles provided $5.7 \pm 1.4 \mathrm{~d}$ of depth utilisation data (range $=3.3$ to $7.1 \mathrm{~d}$ ), and the mean maximum

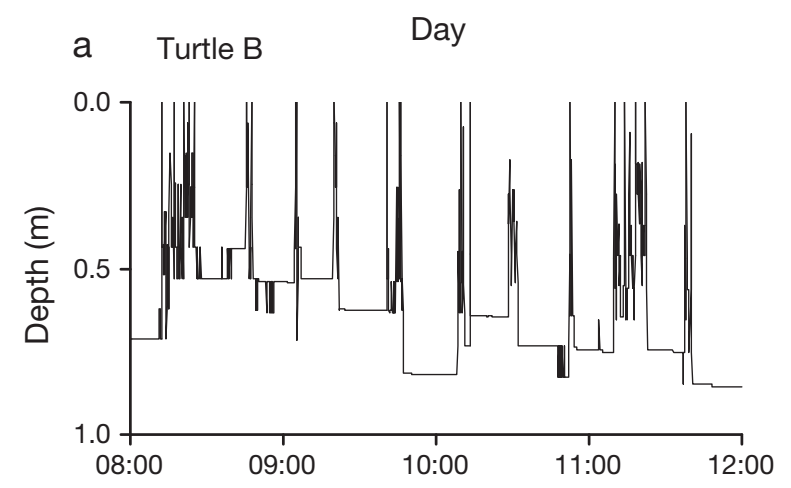

\section{b Turtle D}
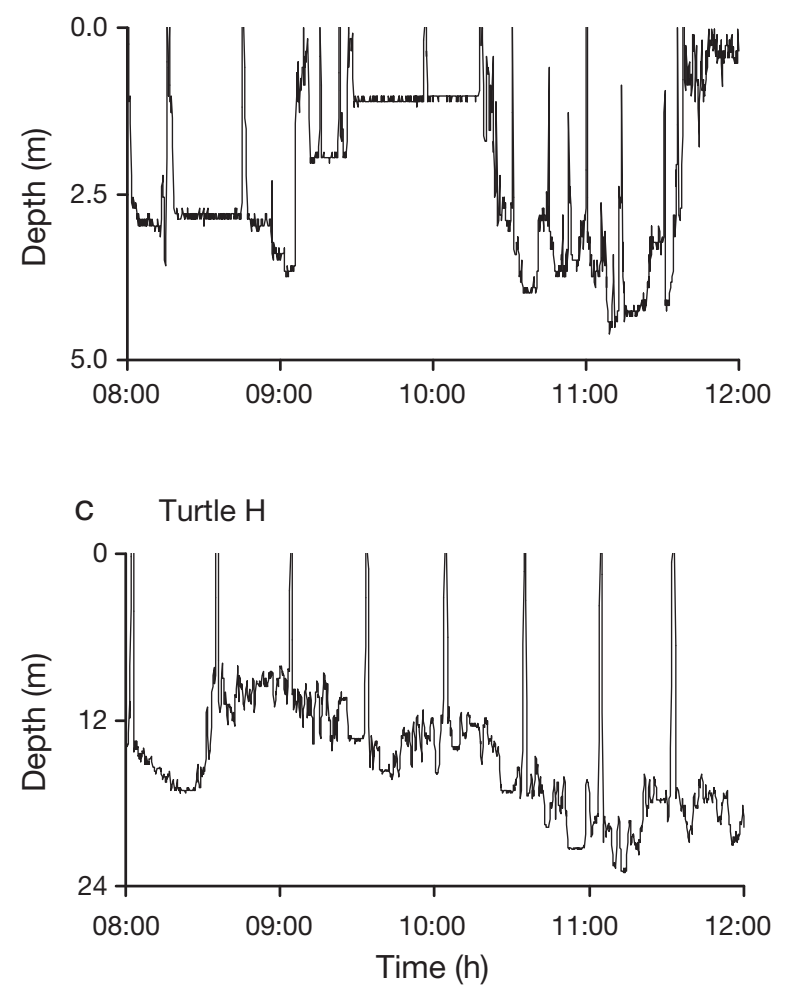

dive depth was $5.1 \pm 7.4 \mathrm{~m}$ (range $=1.0$ to $23.3 \mathrm{~m}$ ). The absolute maximum depth recorded for each turtle did not correlate with CCL (Spearman rank correlation, $\left.\mathrm{r}_{\mathrm{S}}=0.32, \mathrm{p}=0.40\right)$ or time at liberty $\left(\mathrm{r}_{\mathrm{S}}=0.54, \mathrm{p}=0.14\right)$. Turtle H (54 cm CCL) achieved the maximum depth recorded among the study group, reaching $23.3 \mathrm{~m}$ at 21:35 h on Day 7 of TDR deployment.

Daylight maximum dive depths (mean of means = $1.7 \pm 3.1 \mathrm{~m}$, range $=0.4$ to $18.1 \mathrm{~m}$ ) did not differ significantly from night-time dive depths (mean of means = $1.8 \pm 3.7 \mathrm{~m}$, range $=0.4$ to $19.5 \mathrm{~m} ; \mathrm{GLMM}$, Wald $=0.05$, $\mathrm{p}=0.83$; Fig. 3). Dives undertaken during the hours of darkness $(16.0 \pm 12.0 \mathrm{~min}$, range $=2.5$ to $61.5 \mathrm{~min})$

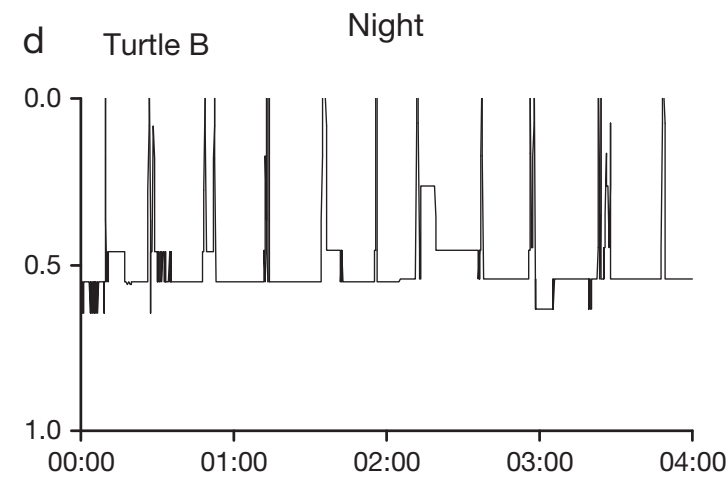

e Turtle D
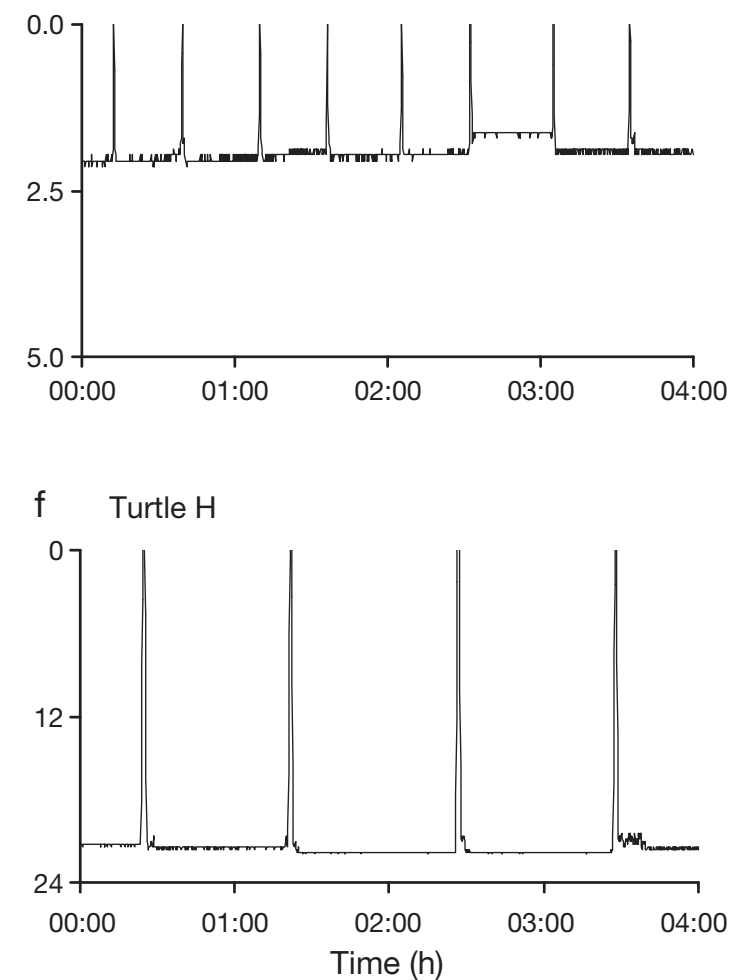

Fig. 3. Eretmochelys imbricata. Temporal pattern of depth utilisation behaviour from Turtles (a) B, (b) D and (c) H during selected periods of day and night 
were significantly longer than those occurring during daylight hours $(7.5 \pm 5.0 \mathrm{~min}$, range $=2.6$ to $34.4 \mathrm{~min}$; Wald $=69.46, p<0.001 ;$ Fig. 3). Turtles demonstrated greater mean $\mathrm{CV}$ for dives made during daylight hours $(0.2 \pm 0.06$, range $=0.06$ to 0.34$)$ than those made during the hours of darkness $(0.13 \pm 0.03$, range $=0.07$ to 0.2 ; Wald $=116.54, \mathrm{p}<0.001$; Fig. 4). There was no relationship between body size (CCL) and dive duration when controlling for the effects of individual and time of day (Wald $=0.34, p=0.58$ ).

\section{Inferred habitat utilisation}

Habitat occupation for 6 individuals (A-C, F, G and I), whose maximum tidally corrected depths were $<3 \mathrm{~m}$, appears to be limited to the inshore reef (Fig. 2a). For Turtles D, E and $\mathrm{H}$, depth utilisation behaviour suggested movement away from the confines of the study area. The minimum straight-line distance between the seabed locations of these turtles' maximum tidally corrected dive depths, 5.5, 5.3 and $22.8 \mathrm{~m}$, respectively, and their recapture locations were $4.8,3.7$ and $9.2 \mathrm{~km}$, respectively (Fig. 2b), at locations outside the study area. Turtle $\mathrm{H}$ attained the greatest depth, $23.3 \mathrm{~m}$, and was at liberty for $32 \mathrm{~d}$. Seabed depths matching to this dive depth, once corrected for tidal pattern $(22.8 \mathrm{~m})$, suggest movement northwest of the study site to the reef wall on the Atlantic Ocean-facing coast of Anegada prior to returning to the site (Fig. 2c). The daily maximum depth of this individual increased in a stepwise fashion (Fig. 5c).

\section{DISCUSSION}

Determining patterns of habitat utilisation remains challenging for many juvenile life stages and smaller species, whose movements cannot be tracked with larger satellite-communicating and dead-reckoning devices; VHF methodologies can be used in these situations, as equipment is typically small, relative to body size. However, in most situations, acoustic or VHF tracking requires researchers to follow equipped individuals. Visual surveying efforts have provided considerable knowledge on the behaviour of marine turtles in foraging habitats (Houghton et al. 2003, Schofield et al. 2006), yet the presence of researchers could represent a disturbing force, and some areas may be inaccessible. Static acoustic monitoring arrays can be used to track the movements of individuals fitted with acoustic transmitters (Blumenthal et al. 2009b); however, this commonly requires a large financial investment to resolve movement at fine scales. These fiscal and logistical obstacles should not, however, detract from gath-

\section{a Turtle A}

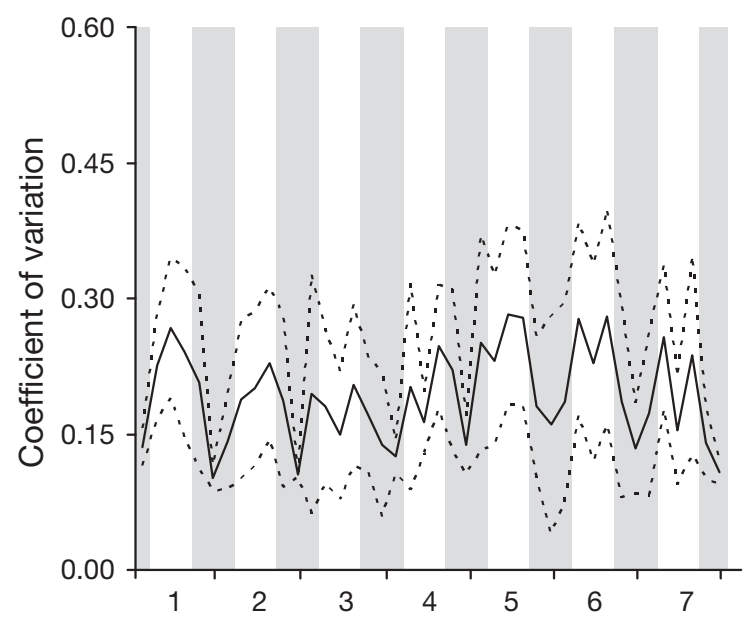

b Turtle D

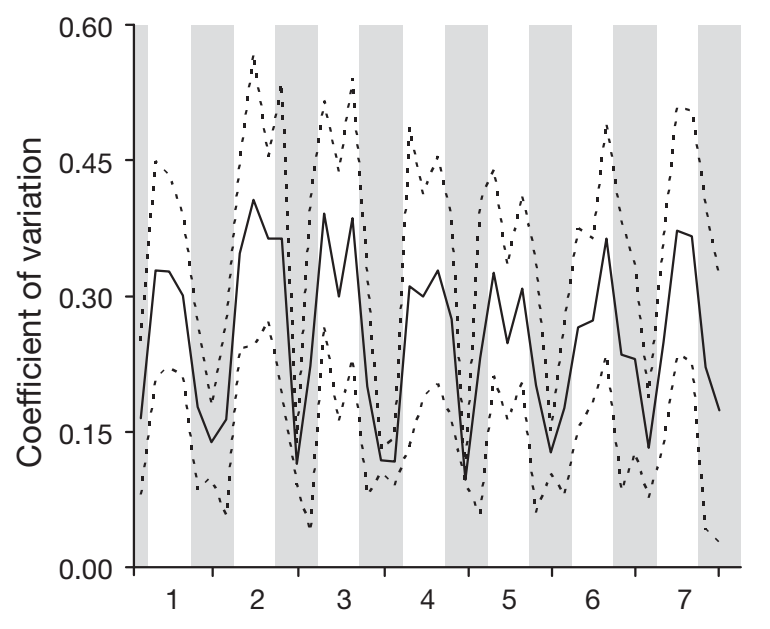

C Turtle $\mathrm{H}$

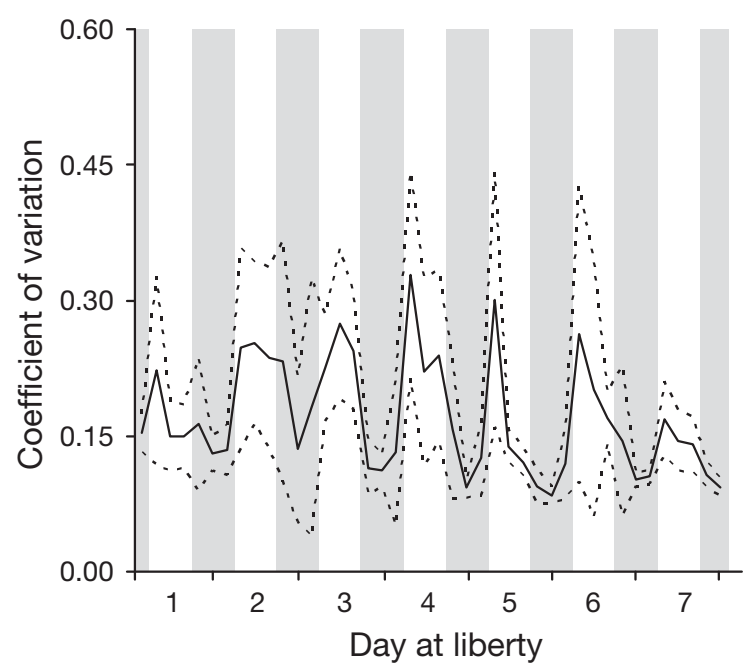

Fig. 4. Eretmochelys imbricata. Mean 4-hourly pattern (solid line) of dive coefficient of variation for Turtles A, D and H. Dashed lines are \pm SD. Periods of night, approximating to 18:00 to $06: 00 \mathrm{~h}$, are indicated by shaded bars 


\section{a Turtle D}

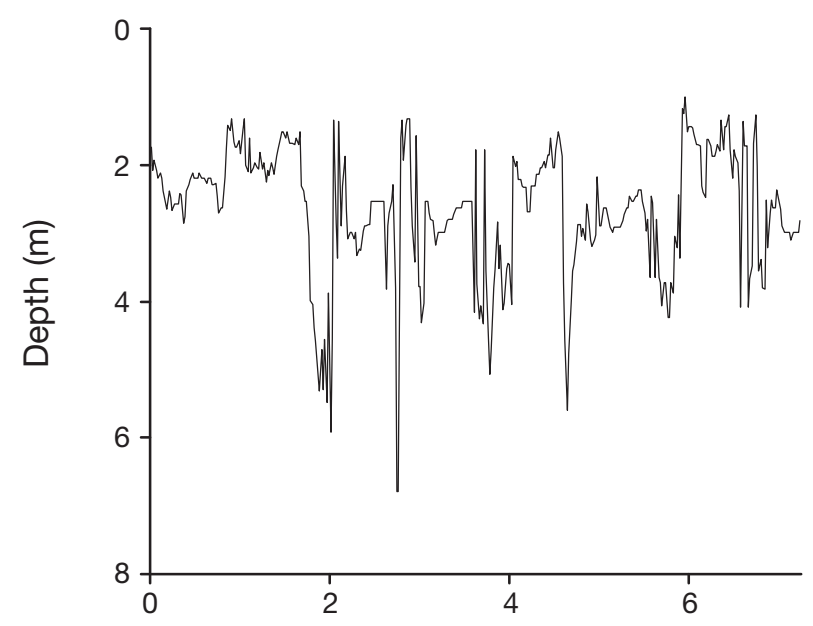

\section{b Turtle E}

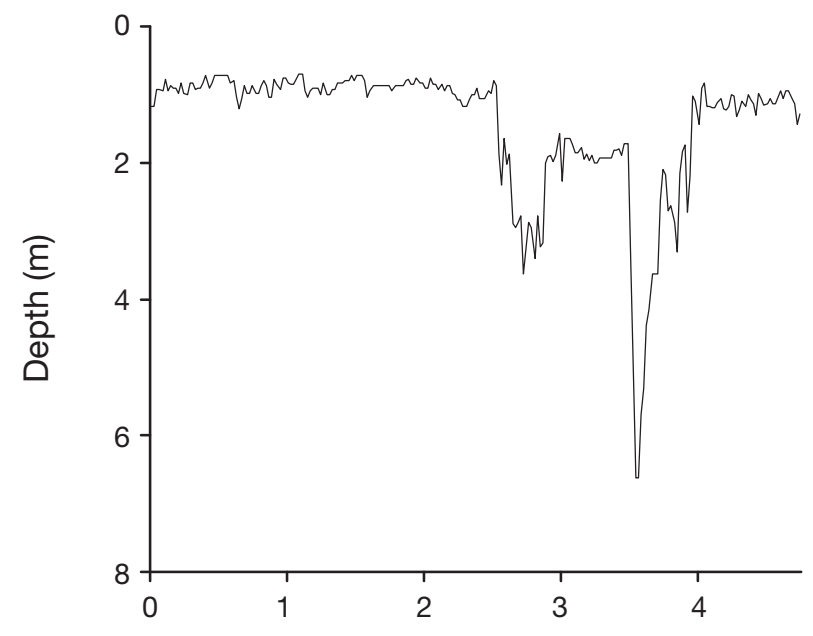

\section{Turtle $\mathrm{H}$}

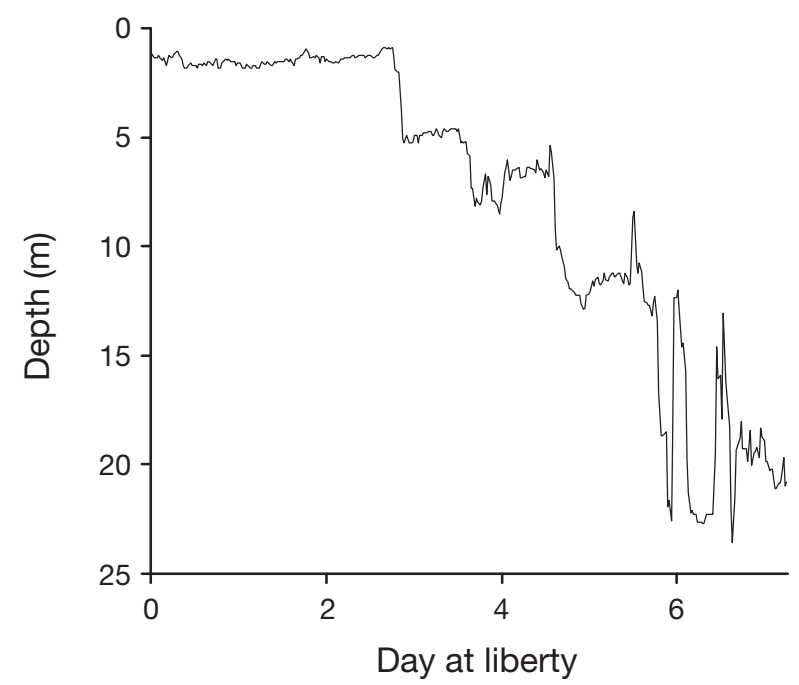

Fig. 5. Eretmochelys imbricata. Tidally corrected 30 min maximum depth profiles during at-liberty time for Turtles D, E and H ering movement data, particularly for species of conservation concern, where bio-logged data are of increasing utility (Cooke 2008).

In the present study the recaptured group of hawksbill turtles provided depth utilisation data from across the size classes of turtles commonly encountered in the inshore reef. There was no apparent scaling of dive metrics (i.e. maximum dive depth, dive duration) with body size, although this may be a reflection of the study site as well as the number and recording duration of the TDRs. This lack of scaling contrasts to that found in similar-sized juvenile hawksbill turtles occupying deeper reef and reef wall habitats, which no doubt provide a greater choice of depths at which to rest and forage (van Dam \& Diez 1996, Blumenthal et al. 2009b). However, the larger individuals in the present study seemed to undertake short-term movements to deeper habitats.

Although turtles were captured and recaptured in shallow-water habitats, the movement of some individuals to deeper water gave preliminary insights into horizontal movements and highlights the possibility of developing inferential geolocation procedures based on TDR data, where movement may be potentially constrained by bathymetry and perhaps habitat preference. Numerous modeling approaches exist which could integrate such constraints, e.g. Bayesian statestate switching models (Haydon et al. 2008), correlated random walk models (Morales et al. 2004, Sims et al. 2006) or models employing levy walk dynamics (Sims et al. 2008). Despite extensive attempts, we were, however, in this case frustrated by the short duration of the TDR data and the lack of a sufficiently high resolution bathymetric model which would have required additional surveying (e.g. side-scan sonar survey data).

The shallow nature of the Anegada inshore reef and the tendency for the instrumented turtles to remain within this region prevented behavioural categories (e.g. foraging, resting) from being consistently assigned to individual dives based on dive profile shape (see Houghton et al. 2002). We could, however, identify a strong diel signal in dive behaviour. Dives made during the hours of darkness were longer and less variable than those undertaken during daylight. Taken together, these observations suggest periods of decreased activity at night, which has been reported for other juvenile and adult hawksbill turtles (Van Dam \& Diez 1996, 1997, Storch et al. 2005, Houghton et al. 2008, Blumenthal et al. 2009b). However, there was no diel difference in dive depths, highlighting the influence of a depthlimited environment on habitat utilisation behaviour.

Fidelity of juvenile hawksbill turtles to the inshore reef observed in the present study and from recapture data collected during long-term monitoring at the site (2003-2006, McGowan et al. 2008) suggest that home 
ranges are small. Yet temporally and spatially limited recapture efforts likely systematically bias home range estimates as small. For the majority of instrumented turtles, depth recordings similarly indicated that movements were most likely constrained to the inshore reef. For 3 individuals, however, the depth utilisation history is suggestive of movement away from the immediate vicinity of the study site. When identifying the tidally corrected maximum depth recorded by turtles on the digital elevation model we see that home ranges may be on the order of several square kilometres or more, somewhat larger than that reported for hawksbill turtles at Mona Island, Puerto Rico $\left(0.07\right.$ to $0.14 \mathrm{~km}^{2}$, van Dam \& Diez 1998), approximately $400 \mathrm{~km}$ west of Anegada.

Although utilisation of TDRs on this species is not new, significant additional insights are possible as a result of deployments at new sites, especially with longer-term data sets within habitats with enhanced bathymetry. Although we failed to obtain more than the most basic insights using inferential geolocation techniques, these have utility in the study of the spatial ecology of other predominantly benthic foraging or resting marine taxa, including crustaceans, molluscs and fishes, but also larger species, including walruses (Bornhold et al. 2005). These approaches will become particularly likely as bio-logged data are becoming increasingly prevalent (Ropert-Coudert et al. 2009), with even further utility when they are interfaced with multi-channel logging technologies currently under development (Wilson et al. 2008). These geolocation techniques could be validated with the advent of newly emerging miniaturised archival GPS technologies (Schofield et al. 2007).

Acknowledgements. M.J.W. is currently supported by the South West of England Regional Development Agency (UK) and the Peninsula Research Institute for Marine Renewable Energy (PRIMaRE) and was in receipt of a Natural Environment Research Council (NERC) PhD studentship (NER/S/A/ 2004/12980). A.C.B. and B.J.G. receive funding from the European Social Fund and NERC. We thank the BVI National Parks Trust for their support and assistance. In addition, we thank the staff and students of Lifeworks for their contribution to fieldwork. This work was part funded by the UK Darwin Initiative (Project Ref No. 162/12/023), NERC and the Japan Bekko Association. All work was sanctioned by the Conservation and Fisheries Department of the British Virgin Islands Government. The manuscript was improved as a result of the comments of 3 anonymous referees.

\section{LITERATURE CITED}

Bjorndal KA (1997) Foraging ecology and nutrition of sea turtles. In: Lutz PL, Musick JA, Wyneken J (eds) The biology of sea turtles, Vol II. CRC Press, Boca Raton, FL, p 199-231 Block BA, Teo SL, Walli A, Boustany A and others (2005) Elec- tronic tagging and population structure of Atlantic bluefin tuna. Nature 434:1121-1127

Blumenthal JM, Austin TJ, Bell CD, Bothwell JB and others (2009a) Ecology of hawksbill turtles, Eretmochelys imbricata, on a western Caribbean foraging ground. Chelonian Conserv Biol 8:1-10

$>$ Blumenthal JM, Austin TJ, Bothwell JB, Broderick AC and others (2009b) Diving behaviour and movements of juvenile hawksbill turtles Eretmochelys imbricata on a Caribbean coral reef. Coral Reefs 28:55-65

Bolten AB (1999) Techniques for measuring sea turtles. In: Eckert KL, Bjorndal KA, Abreu-Grobois FA, Donnelly M (eds) Research and management techniques for the conservation of sea turtles. IUCN/SSC Marine Turtle Specialist Group Publication No. 4, Washington, DC, p 110-114

$>$ Bonfil R, Meyer M, Scholl MC, Johnson R and others (2005) Transoceanic migration, spatial dynamics and population linkages of white sharks. Science 310:100-103

Bornhold BD, Jay CV, McConnaughey R, Rathwell G, Rhynas K, Collins W (2005) Walrus foraging marks on the seafloor in Bristol Bay, Alaska: a reconnaissance survey. Geo-Mar Lett 25:293-299

Cooke SJ (2008) Biotelemetry and biologging in endangered species research and animal conservation: relevance to regional, national and IUCN Red List threat assessments. Endang Species Res 4:165-185 doi:10.3354/esr00063

Cuevas E, Abreu-Grobois FA, Guzmán-Hernández V, LiceagaCorrea MA, van Dam RP (2008) Post-nesting migratory movements of hawksbill turtles Eretmochelys imbricata in waters adjacent to the Yucatan Peninsula, Mexico. Endang Species Res doi:10.3354/esr00128

Duron-Dufrenne M (1987) First satellite-based tracking in the Atlantic ocean of a leatherback turtle Dermochelys coriacea. CR Acad Sci Paris 304:399-402

Godley BJ, Blumenthal J, Broderick AC, Coyne MS, Godfrey MH, Hawkes LA, Witt MJ (2008) Satellite tracking of sea turtles: Where have we been and where do we go next? Endang Species Res 4:3-22

- Haydon DT, Morales JM, Yott A, Jenkin DA, Rosatte R, Fryxell JM (2008) Socially informed random walks: incorporating group dynamics into models of population spread and growth. Proc Biol Sci 275:1101-1109

> Hill MS (1998) Spongivory on Caribbean reefs releases corals from competition with sponges. Oecologia 117:143-150

Hochscheid S, McMahon CR, Bradshaw CJA, Maffucci F, Bentivegna F, Hays GC (2007) Allometric scaling of lung volume and its consequences for marine turtle diving performance. Comp Biochem Physiol A 148:360-367

Houghton JDR, Broderick AC, Godley BJ, Metcalfe JD, Hays GC (2002) Diving behaviour during the internesting interval for loggerhead turtles Caretta caretta nesting in Cyprus. Mar Ecol Prog Ser 227:63-70

> Houghton JDR, Callow MJ, Hays GC (2003) Habitat utilization by juvenile hawksbill turtles (Eretmochelys imbricata, Linnaeus, 1766) around a shallow water coral reef. J Nat Hist 37:1269-1280

> Houghton JD, Cedras A, Myers AE, Liebsch N, Metcalfe JD, Mortimer J, Hays GC (2008) Measuring the state of consciousness in a free-living diving sea turtle. J Exp Mar Biol Ecol 356:115-120

Hunter E, Aldridge JN, Metcalfe JD, Arnold GP (2003) Geolocation of free-ranging fish on the European continental shelf as determined from environmental variables. I. Tidal location method. Mar Biol 142:601-609

Hunter E, Berry F, Buckley AA, Stewart C, Metcalfe JD (2006) Seasonal migration of thornback rays and implications for closure management. J Appl Ecol 43:710-720 
León YM, Bjorndal KA (2002) Selective feeding in the hawksbill turtle, an important predator in coral reef ecosystems. Mar Ecol Prog Ser 245:249-258

Limpus CJ, Reed P (1985) The green turtle, Chelonia mydas, in Queensland: a preliminary description of the population structure in a coral reef feeding ground. In: Grigg GC, Shine R, Ehmann H (eds) Biology of Australasian frogs and reptiles. Royal Zoological Society of New South Wales, Sydney, p 47-52

McGowan A, Broderick AC, Frett G, Gore S and others (2008) Down but not out: marine turtles of the British Virgin Islands. Anim Conserv 11:92-103

Metcalfe JD, Arnold GP (1997) Tracking fish with electronic tags. Nature 387:665-666

Meylan AB (1988) Spongivory in hawksbill turtles: a diet of glass. Science 239:393-395

Meylan AB (1999) International movements of immature and adult hawksbill turtles (Eretmochelys imbricata) in the Caribbean region. Chelonian Conserv Biol 3:189-194

Morales JM, Haydon DT, Frair J, Holsiner KE, Fryxell JM (2004) Extracting more out of relocation data: building movement models as mixtures of random walks. Ecology 85:2436-2445

Mori Y (2002) Optimal diving behaviour for foraging in relation to body size. J Evol Biol 15:269-276

Musick JA, Limpus CJ (1997) Habitat utilization and migration in juvenile sea turtles. In: Lutz PL, Musick JA (eds) The biology of sea turtles, Vol 1. CRC Press, Boca Raton, FL, p 432

Pavlov VV, Wilson RP, Lucke K (2007) A new approach to tag design in dolphin telemetry: computer simulations to minimise deleterious effects. Deep-Sea Res Part II 54:404-414

Polovina JJ, Kobayashi DR, Parker DM, Seki MP, Balazs GH (2000) Turtles on the edge: movement of loggerhead turtles (Caretta caretta) along oceanic fronts, spanning longline fishing grounds in the central North Pacific, 1997-1998. Fish Oceanogr 9:71-82

Priede IG (1984) A basking shark (Cetorhinus maximus) tracked by satellite together with simultaneous remote sensing. Fish Res 2:201-216

Righton D, Mills CM (2008) Reconstructing the movements of free-ranging demersal fish in the North Sea: a datamatching and simulation method. Mar Biol 153:507-521

Ropert-Coudert Y, Beaulieu M, Hanuise N, Kato A (2009)

Editorial responsibility: Brent Stewart,

San Diego, California, USA
Diving into the world of biologging. Endang Species Res doi:10.3354/esr00188

Schofield G, Katselidis KA, Dimopoulos P, Pantis JD, Hays GC (2006) Behaviour analysis of the loggerhead sea turtle Caretta caretta from direct in-water observation. Endang Species Res 2:71-79

- Schofield G, Bishop CM, MacLean G, Brown P and others (2007) Novel GPS tracking of sea turtles as a tool for conservation management. J Exp Mar Biol Ecol 347:58-68

Sims DW, Witt MJ, Richardson AJ, Southall EJ, Metcalfe JD (2006) Encounter success of free-ranging marine predator movements across a dynamic prey landscape. Proc Biol Sci 273:1195-1201

- Sims DW, Southall EJ, Humphries NE, Hays GC and others (2008) Scaling laws of marine predator search behaviour. Nature 451:1098-1102

Storch S, Wilson RP, Hillis-Starr ZM, Adelung D (2005) Coldblooded divers: temperature-dependent dive performance in the wild hawksbill turtle Eretmochelys imbricata. Mar Ecol Prog Ser 293:263-271

van Dam RP, Diez CE (1996) Diving behavior of immature hawksbills (Eretmochelys imbricata) in a Caribbean cliffwall habitat. Mar Biol 127:171-178

van Dam RP, Diez CE (1997) Diving behavior of immature hawksbill turtles (Eretmochelys imbricata) in a Caribbean reef habitat. Coral Reefs 16:133-138

van Dam RP, Diez CE (1998) Home range of immature hawksbill turtles (Eretmochelys imbricata (Linnaeus)) at two Caribbean islands. J Exp Mar Biol Ecol 220:15-24

van Dam RP, Diez CE, Balazs GH, Colón LAC, McMillan WO, Schroeder B (2008) Sex-specific migration patterns of hawksbill turtles breeding at Mona Island, Puerto Rico. Endang Species Res 4:85-94

> Watson KP, Granger RA (1998) Hydrodynamic effect of a satellite transmitter on a juvenile green turtle (Chelonia mydas). J Exp Biol 201:2497-2505

Wilson RP, McMahon CR (2006) Measuring devices on wild animals: What constitutes acceptable practice? Front Ecol Environ 4:147-154

Wilson RP, Shepard ELC, Liebsch N (2008) Prying into the intimate details of animal lives: use of a daily diary on animals. Endang Species Res 4:123-137

Zar JH (1999) Biostatistical analysis, 4th edn. Prentice Hall, Upper Saddle River, NJ

Submitted: September 18, 2009; Accepted: January 11, 2010 Proofs received from author(s): February 17, 2010 